\title{
ENGINEERING GEOLOGICAL MAP OF THE URBAN AREA OF KASTORIA, NW GREECE
}

\author{
Konstantopoulou G. ${ }^{1}$, and Vacondios I. ${ }^{1}$ \\ ${ }^{1}$ Institute of Geology and Mineral Exploration (I.G.M.E.), Mesogion Str. 70, 115 27, Athens \\ kongar@igme.gr
}

\begin{abstract}
In the present work, the engineering geological conditions of the urban area of Kastoria were examined. More specifically a geotechnical assessment of subsoil and rock outcrops within a minimum depth of $20 \mathrm{~m}$ bellow surface is made, for urban planning purposes. Landslide potential of the studied area including mainly rock falls and ground subsidence was also evaluated. Eleven engineering geological units were identified and mapped at 1:5.000 scale, which constitute the foundation ground of the old Kastoria town, as well as of its new areas of built-up extension. The identified ground units consist of six soil and five rock types. Soil units comprise one fill formation of variable composition and consistency with a ranging thickness between $2 \mathrm{~m}$ and $6 \mathrm{~m}$ and five loose to cohesive deposits, Holocene to Upper Pliocene in age, with high variation in grain size, density and plasticity factors. Rock lithologies range from highly to moderately weathered, closely fractured serpentinites and schists to fresh, widely fractured limestones. The old city of Kastoria is founded mainly on stable rocky ground and does not show any remarkable geotechnical problems. However, the need of built-up extension however and improvement of infrastructures, led to configurations of the marshy areas and to the use of foundation ground with poor mechanical properties, which locally need a special treatment to become stable.
\end{abstract}

Key words: Mechanical properties, urban planning, natural hazards.

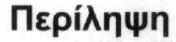

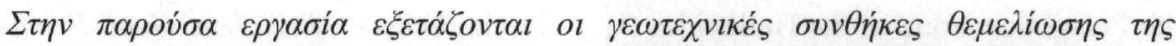

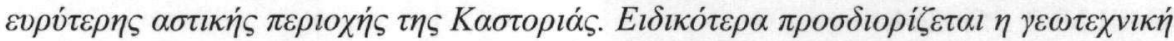

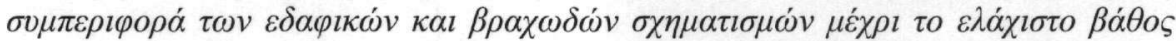

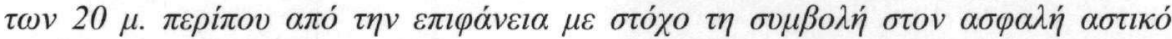

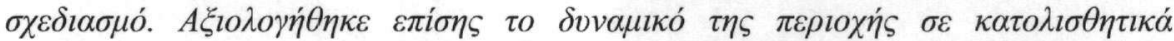

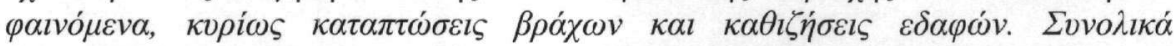

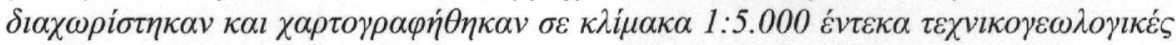

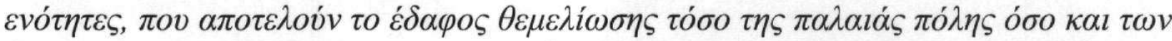

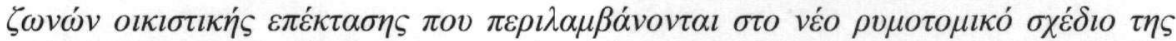

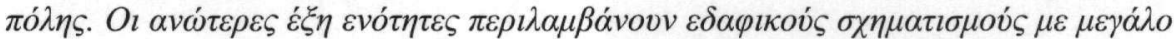

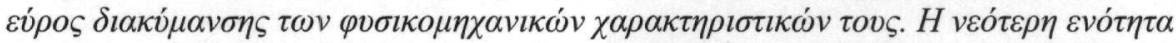

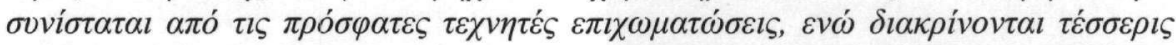

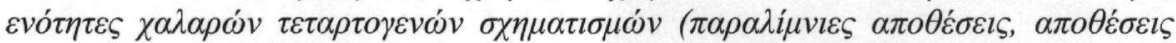

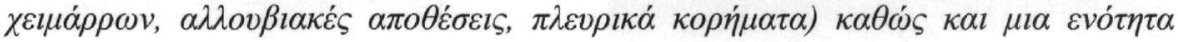




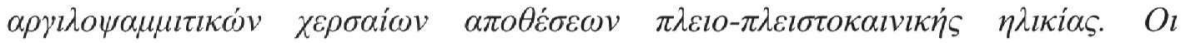

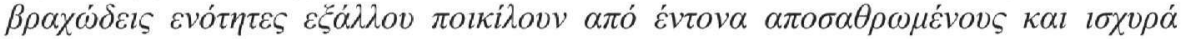

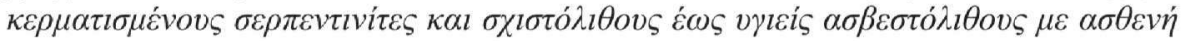

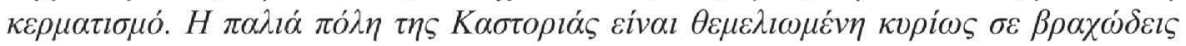

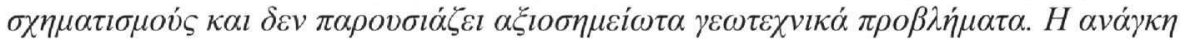

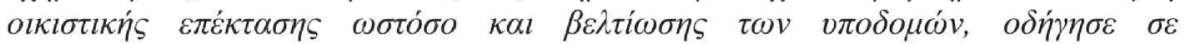

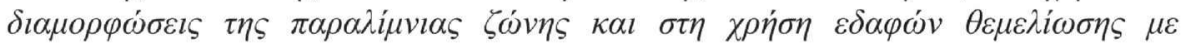

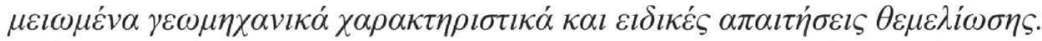

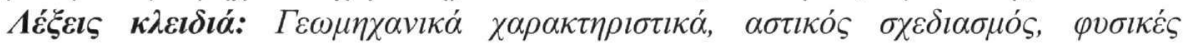

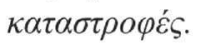

\section{Introduction}

Although a small town of about 20,000 habitants, Kastoria follows the evolution trend of all modern towns, with considerable lateral expansion, in parallel with its vertical growth. For design of any civil engineering project it is essential to determine engineering properties of the site of intended structure, which are locally obtained by geotechnical investigations. While site-specific investigations give the detailed profile of engineering properties, the town planners require more general information of engineering properties of the area designed for urban development.

Investigations have not so far been made to evaluate the basic geotechnical conditions of the foundation ground of Kastoria, and no systematic study has been made to combine the data available, in order to draw a general picture of the sub-soil pattern for use as a planning site guide or in making preliminary assessment of foundation requirements of new projects.

The present work is an attempt to this direction. Thus, a multipurpose engineering geological map of the broad urban area of Kastoria was conducted at 1:5,000 scale, comprising the identification, description and classification of rock and soil types for engineering purposes, in parallel with the geohazard assessment of the studied area.

\section{Geomorphology}

The old traditional town of Kastoria with its multiple listed monuments (Byzantine churches, neoclassic buildings and mansion houses) has been developed on the smooth oblong part of the peninsula of Koritsa, on the western side of Orestias lake.

Not only Koritsa peninsula but also all the western lakeside area has a mountainous relief, with high morphological gradients and bold lake cliffs, particularly south of the old town area, whereas the altitudes range between $620 \mathrm{~m}$ (lake surface) up to $1100 \mathrm{~m}$.

Hydrographic network is well defined within the northern urban area, whereas at least six main sub parallel stream axes are developed along a NW-SE direction, which debouch directly into the lake. While stream beds are well defined in the north-western area of higher altitudes, when they enter into the flat urban area, they become obscure.

The growth of population during the last decades and the change in the way of living, led to a continuous urban expansion, in either sides of the old town, along the western lakeside, in an N-S direction. Due to geomorphologic restrictions, the main urban expansion goes northwards and to a lesser degree towards the south. The parallel strong demand of sufficient space in close distance to the town for development of basic infrastructures, led to the extensive backfilling of the lakeside zone, especially along the southern entrance of the town. The lake platform and the road by the shore of the lake, as well as a car parking were founded on the backfilling zone. 


\section{Geological - hydrogeological framework}

The metamorphic rocks cropping out within Kastoria area belong to the crystalline basement of Pelagonian Zone (Mountrakis 1974). The main lithologies include Paleozoic gneisses, schists and amphibolites, recording a polyphase tectono-metamorphic evolution. These are followed up by Triassic limestones, dolomitic limestones and ophiolitic rock segments. The Pelagonian formations constitute the rocky outcrops of irregular topography, while flat areas usually consist of Tertiary to Quaternary deposits.

The area of Kastoria exhibits wet mesothermal climate with an average minimum and maximum annual temperature of $-2.2^{\circ} \mathrm{C}$ (January) and $29.5^{\circ} \mathrm{C}$ (July-August). The average annual rainfall is $719.7 \mathrm{~mm}$, the most of which falls during winter.

The geological formations exhibit a diverse hydrogeological behaviour according to their lithological characteristics, ranging from highly pervasive formations (loose coarse grain deposits, limestone units) to waterproof formations (clayey silty sediments, schists, ophhiolitic rocks etc).

\section{Methodology}

Apart from the detailed field mapping at 1:5.000 scale, geotechnical data of past site investigation reports were collected and evaluated in order to identify the sub-soil physical and mechanical characteristics of the town of Kastoria. Existing drilling sections were used to check the subsurface geometry of geological formations. Moreover samples from 16 shallow exploratory pits $2.5-4.5 \mathrm{~m}$ deep, were analysed for engineering properties in the laboratory of IGME, Engineering Geology Dpt. These properties included grain size distribution, liquid limit (LL) and plastic limit (PL), moisture content and specific gravity test. All tests were performed according to relevant ASTM standards. Information on Standard Penetration Test (SPT) as well as mechanical properties of rock units were obtained from geotechnical reports of the construction companies.

Geotechnical database for the area of study was designed to store the field and laboratory data from site investigations and geotechnical information collected from previous reports. The database is linked to Arc 9.1 Geographic Information System (GIS) software, which graphically produces thematic maps.

\section{Geotechnical units}

Systematic field investigation is the main source of acquiring regional engineering geological information. Kastoria urban area consists of diverse and complex territory formations, which had grouped into geotechnical units with a certain extent of homogeneity and of engineering geological similarity with regard to construction and other land-use purposes.

A multipurpose surface engineering geological map was accordingly prepared at an original scale of 1:5,000, with a subdivision of 11 engineering geological rock and soil units (Fig. 2). The preparation of the engineering geological map adhere to the recommendations of the IAEGUNESCO (1976) and the Mapping Commission (1980). The eleven (11) foundation ground units that have been distinguished within the broad urban area of Kastoria are as follow:

\section{Recent fills}

They are composed by heterogeneous materials of various size and composition including limestone blocks and stones mixed with coarse grained soils, mortar, and other construction debris, products of excavations or demolitions. Fill materials up to $5 \mathrm{~m}$ thick were deposited on the soft marshy formations, along the lakeside of the southern entrance of the old town, in a zone about 50 $\mathrm{m}$ wide by $2000 \mathrm{~m}$ long. The overloading of the underlying soft materials led them gradually to side slip towards the lake, where small "islands" were floated to the surface in a distance of 20-30 $\mathrm{m}$ from the shore. Although light constructions were founded on the backfilling zone including the 


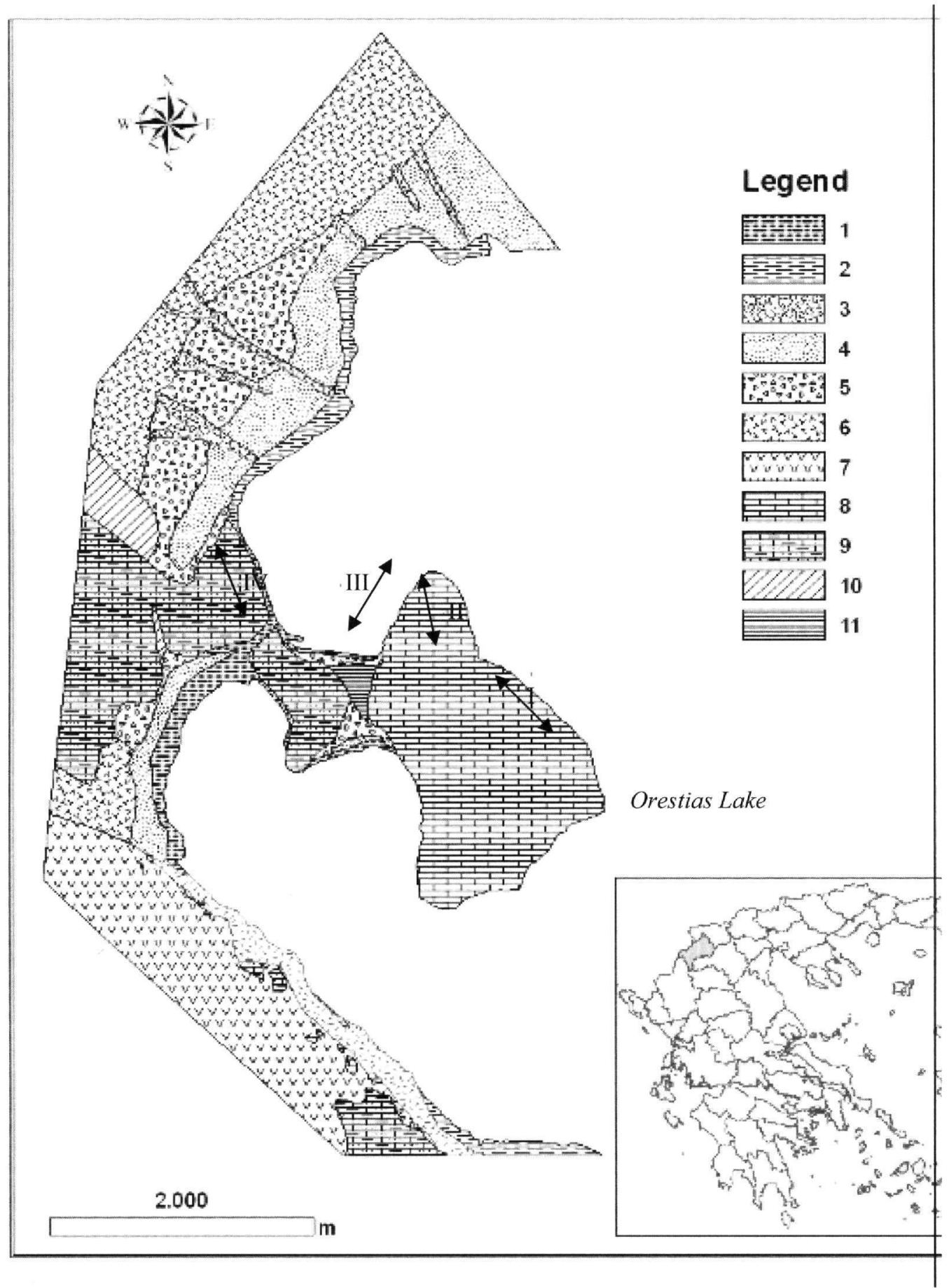

Figure 1 - Simplified enginearing geological map of Kastoria urban area: 1. Recent fills, 2.Lakeside marshy deposits, 3. Riverbed deposits, 4. Alluvial deposits, 5. Lateral screes, 6. PlioPleistocene sediments, 7. Ophiolitic unit, 8. Limestones, 9. Triassic limestones and dolomitic limestones, 10. Palaeozoic to Lower Triassic semi-metamorphic unit, 11. Palaeozoic (undifferentiated). I, II, III, IV: Slopes with high rock fall susceptibility (Fig.2). Identification of ground subsidence areas, their mechanism of occurrence, as well as rock stability analysis in slopes with relatively high rock fall susceptibility, were also performed. 
central road, a car parking, the open market etc, ground subsidence phenomena have been occurred. Subsidence results in local flooding of the lake, while damages on the existing foundations also occur within a distance of about $80 \mathrm{~m}$ from the lakeside. Man-made deposits with a maximum thickness of 2,5 $\mathrm{m}$ have been also deposited in certain places of the northern extension of the town. These loose materials must be removed as they constitute foundation ground of poor geotechnical characteristics.

\section{QUATERNARY FORMATIONS}

\section{Lakeside marshy deposits:}

This unit consists of soft viscous clayed silts, with high organic content, dark grey in colour, with a minimum thickness of 8 metres (usually 10-25 m.). A shell- rich horizon is common at the depth of $10-12 \mathrm{~m}$. The unit is characterized by medium grade plasticity, high compressibility and very low bearing capacity, resulting in big subsidence under loading and therefore becoming a problematic foundation soil, that needs specials treatment if it cannot be avoided. The unit occurs in several parts of the lakeside area and constitutes also the basement of the lake.

\section{Riverbed deposits}

Loose heterogeneous unit consisting of coarse-grained materials containing gravels, sands, grits and cobbles, with minor amount of silts. They have been deposited within the lower part of the stream sections, within a distance of 20 to $80 \mathrm{~m}$ from the stream axes, with maximum thickness of $3,5 \mathrm{~m}$.

\section{Alluvial deposits}

Loose to semi-coherent heterogeneous materials forming crossing layers of brownish-red clays and silts with thin intercalations of silty sands to coarse sands mixed with grits and gravels. They are characterized by low to medium plasticity and hydraulic conductivity, displaying a high variation in phase composition, in both horizontal and vertical direction. The unit has a maximum thickness of $15 \mathrm{~m}$ and constitutes the greatest part of the flat urban area. It exhibits a non-uniform geotechnical behaviour, which must be considered during foundation.

\section{Screes}

Heterogeneous unit consisting of polygenetic angular fragments mixed with sands and sandy gravels as well as fine-grain materials such as clayey silts and silty sands in a small percentage. The thickness of the unit increases gradually from west to east, reaching a maximum of about $10 \mathrm{~m}$. They are usually characterized by medium grade diagenesis, and generally good geotechnical behaviour.

\section{PLIO-PLEISTOCENE SEDIMENTS}

This unit consists of thin intercalations of sands, silty sands and loams, while lense-shape concentrations of grits and gravels are locally present. In the northern part of the town it appears brown-reddish in colour, generally semi-cohesive with loose sandy layers. In the south part of the town Plio-Pleistocene formations are mostly fine-grained, light yellow-brown, with higher grade coherence. It is generally characterized with good mechanical properties and no significant instabilities have been observed.

\section{Ophiolitic unit}

Ophiolitic unit includes mafic and ultramafic rocks, mainly peridotites with amphibolite lenses as well as ophiolitic melanges. They exhibit intense tectonism and serpentinisation. They often contain chromite concentrations and $\mathrm{Fe}-\mathrm{Ni}$ ores. Two main joint systems were measured: a) $55 / 140$ and b) $70 / 170$ and three secondary systems: a) $60 / 285$, b) $65 / 350$ and c) $70 / 210$. The ophiolitic unit generally constitutes a good foundation ground. However in high cut slopes of the southern central road leading to the town, landslides occurred recently, causing the temporal 
closure of the road, up to the repairing measures. The highly fractured serpentine mass along with the height and steepness of the slope were the main reasons for the landslide occurrence.

\section{Limestones}

Limestone unit is thick bedded, light to dark grey in colour. Layering is the main system of discontinuities, having light undulate growth around a mean direction ranging from $\mathrm{N} 200{ }^{\circ} \mathrm{E}$ to $\mathrm{N} 240^{\circ} \mathrm{E}$ and dipping $10^{\circ}$ and $45^{\circ}$. The limestone unit is cutted by a dense network vertical and sub vertical faults, with displacement ranging from a few centimetres up to $1,5 \mathrm{~m}$, that usually have the following directions: NNE-SSW, N-S, ENE-WSW and WNW-ESE. All the discontinuity systems are generally dense and continuous, with rough surface and local dissolution phenomena. Discontinuities are often filled by red plastic clays mixed with limestone fragments. It has in general good geomechanical behaviour, with RQD between $62 \%$ and $100 \%$. At places however intense fragmentation of the rock due to intense tectonism was observed. Thus, in the very steep slopes around the circumferential lake road, especially in the eastern and northern part of the Koritsa peninsula, rock falls are very likely to occur.

\section{TRIASSIC LIMESTONES AND DOLOMITIC LIMESTONES}

They are constituted from medium to thick bedded light grey recrystallised limestones that become dark grey to black in colour. The upper part of the unit contains schist and chert intercalations of various thicknesses. High rockfall susceptibility was detected in the cut slope of the central lakeside road that leads out the north part of old city.

\section{PALAEOZOIC TO LOWER TRIASSIC SEMI-METAMORPHIC UNIT}

It consists mainly of meta-conglomerates and meta-sandstones with lenticular intercalations of red limestones, schists and phylites, as well as fine-grain meta-sediments of low grade metamorphism. Most discontinuities were observed to be rough without significant evidence of weathering, slickensliding nor the presence of clay gauge. The unit exhibits in general a good geomechanical behaviour, although locally intensively sheared

\section{PALAEOZOIC (undifferentiated)}

This unit has a limited occurrence within a small part of the old town of Kastoria. It is an intensely deformed and metamorphic system that includes gneisses, schists and amphibolites. Generally, it is a cohesive rock that is characterized by undulate, closed schistosity. Quartz vein 1-5 cm thick fragments appear locally forming a mosaic texture. Fault and join discontinuities are generally rare and the rock mass appears quite fresh and exhibits good geomechanical behaviour.

\subsection{Soil unit properties}

Table 1 summarises the range of physical and mechanical properties of the six soil units occurring within the urban area of Kastoria. Laboratory tests were performed on 20 samples taken from 16 exploratory pits, the most of which were opened within the last three units constituting a greater part of the foundation ground of Kastoria town.

\subsection{Rock mass properties}

There are many classifications of rock mass quality (Barton et al. 1974), some of which assign numerical values to properties of rocks. The Rock Mass Rating (RMR) system proposed by Bieniawski (1989) is a composite rock property taking into account several parameters including strength of intact rock, Rock Quality Designation (RQD), spacing of discontinuities, degree of weathering and groundwater. According to RMR rock mass is classified in five categories, as follows: I) very good rock (81-100), II) good (61-80), III) fair (41-60), IV) poor (21-40) and V) very poor rock $(<20)$. Individual parameters been measured in the field in combination with a limited number of existing laboratory data give a general frame of the geotechnical characteristics of the identified rock units. The summary of those results are given in table 2 . All the mapped rock 
units fall within Class II (Good Rock) and Class V (Very Poor Rock), with the exception of unit 8 (J1-k), been locally characterized as good to very good rock mass.

Table 1 - Laboratory Soil Parameters

\begin{tabular}{|c|c|c|c|c|c|}
\hline $\mathbf{N}$ & $\begin{array}{l}\text { GEOTECHNI- } \\
\text { CAL UNIT }\end{array}$ & $\begin{array}{c}\text { SOIL } \\
\text { TYPE } \\
\text { (AUSCS) }\end{array}$ & $\begin{array}{c}\text { RANGE OF } \\
\text { THICKNESS } \\
(\mathbf{m})\end{array}$ & \multicolumn{2}{|c|}{$\begin{array}{l}\text { PHYSICAL AND MECHANICAL PROPERTIES } \\
\text { (range of values from laboratory tests) }\end{array}$} \\
\hline 1 & Recent fills & & $0,5-5$ & & \\
\hline 2 & $\begin{array}{l}\text { Lakeside marshy } \\
\text { deposits }\end{array}$ & $\mathrm{CL}, \mathrm{ML}$ & $8-12$ & \\
\hline 3 & Riverbed deposits & $\begin{array}{l}\text { GW, GM, } \\
\text { CL }\end{array}$ & $<3,5$ & \multicolumn{2}{|l|}{$\mathrm{qc}<980 \mathrm{kPa}$} \\
\hline & & & & Coarse grains horizons & Fine grains horizons \\
\hline 4 & Alluvial deposits & $\begin{array}{l}\text { SM, GS, } \\
\text { CL }\end{array}$ & $<15$ & $\begin{array}{l}\text { Grain size analysis: } \\
\text { gravels } 14-36 \% \text {, sands } \\
33-64 \% \text {, silts and clays } \\
12-37 \%) \\
\text { LL }(\%)=25.0-27.2 \\
\text { PL(\%): } 21.0-34.0 \\
\mathrm{w}(\%): 10.7-34.9 \\
\mathrm{~N}_{\text {SPT }}: 5-30 \text { (usually } 12- \\
24) \\
\gamma_{\mathrm{b}}=\left(\mathrm{kN} / \mathrm{m}^{3}\right): 17.7-20.6 \\
\mathrm{q}_{\mathrm{u}}(\mathrm{kPa}): 93,2-125,5 \\
\varphi: 35^{\circ}\end{array}$ & $\begin{array}{l}\text { Grain size analysis: gravels } \\
1-19 \% \text {, sands } 35-48 \% \text {, silts } \\
\text { and clays } 44-58 \%) . \\
\text { LL(\%)=36.2-43.6 } \\
\text { PL }(\%): 31.0-37.8 \\
\text { w }(\%): 10.7-34.9 \\
\text { e: } 0.35-0.46 \\
\left.N_{\text {SPT }}: 5-34 \text { (usually }>34\right) \\
q_{u}(\mathrm{kPa}): 127.5-186.3 \\
\text { c }(\mathrm{kPa}): 9.81 \\
\varphi: 32^{\circ}\end{array}$ \\
\hline 5 & Screes & $\mathrm{SC}$ & $2-10$ & $\begin{array}{l}\mathrm{w}(\%): 10-17 \% \\
\gamma_{\mathrm{b}}=\left(\mathrm{kN} / \mathrm{m}^{3}\right): 17.7-20.6\end{array}$ & $\begin{array}{l}\mathrm{q}_{\mathrm{u}}(\mathrm{kPa}): 137.3-186.3 \\
\mathrm{c}(\mathrm{kPa}): 0.0-19.6 \\
\varphi: 12^{\circ}-23^{\circ}\end{array}$ \\
\hline 6 & $\begin{array}{l}\text { Plio-Pleistocene } \\
\text { sediments }\end{array}$ & $\mathrm{CL}, \mathrm{SC}$ & $5-60$ & \multicolumn{2}{|c|}{$\begin{array}{l}\text { w }(\%): 10,0-25,0, \text { LL }(\%): 17,0-30,0, \\
\gamma_{\mathrm{b}}\left(\mathrm{kN} / \mathrm{m}^{3}\right): 17.7-21.6, \mathrm{q}_{\mathrm{u}}(\mathrm{kPa}): 68.6-245.2 \\
\mathrm{c}(\mathrm{kPa}): 0.0-19.6, \varphi: 14^{\circ}-35^{\circ}\end{array}$} \\
\hline
\end{tabular}

Table 2 - Rock units Parameters

\begin{tabular}{|c|c|c|c|}
\hline $\mathbf{A} / \mathbf{A}$ & GEOTECHNICAL UNIT & $\begin{array}{l}\text { ROCK MASS } \\
\text { QUALITY* }\end{array}$ & $\begin{array}{c}\text { MECHANICAL PROPERTIES } \\
\text { (range of values from laboratory } \\
\text { tests) }\end{array}$ \\
\hline 7 & Ophiolitic unit & IV - V & $\begin{array}{l}q_{u}(\mathrm{kPa}): 1961-147000 \\
\varphi: 26^{\circ}-48^{\circ} \\
E(\mathrm{kPa}): 3920-24500\end{array}$ \\
\hline 8 & Limestones & II - VI & $\begin{array}{l}q_{u}(k P a): 39200-97700 \\
c(k P a): 440-4380 \\
\varphi: 51^{\circ} 51,5^{\circ} \\
E(k P a): 9800-27636\end{array}$ \\
\hline 9 & $\begin{array}{l}\text { Limestones and dolomitic } \\
\text { limestones }\end{array}$ & III - IV & $\begin{array}{l}\gamma_{\mathrm{b}}\left(\mathrm{kN} / \mathrm{m}^{3}\right): 22,6-26.5 \\
q_{u}(\mathrm{kPa}): 78480-68670 \\
\varphi: 35^{\circ}-45^{\circ}\end{array}$ \\
\hline 10 & $\begin{array}{l}\text { Palaeozoic to Lower Triassic semi- } \\
\text { metamorphic unit }\end{array}$ & III - IV & \\
\hline 5 & Palaeozoic & IV $-V$ & \\
\hline
\end{tabular}




\subsection{Geological Hazards}

Local instability phenomena were observed within the area of study during field mapping, including mainly rock falls, rotational landslides as well as ground subsidence.

\subsubsection{Rock falls}

Rock falls of any scale occur in different places within the broad urban area of Kastoria. The very steep slopes especially in the northern and eastern part of the Koritsa peninsula, which is structured by Limestones unit, has a high rockfall susceptibility. A similar high susceptibility appears in the cut slope of the lakeside road leading out the north exit of the town. This slope is built up by the dolomitic formation.
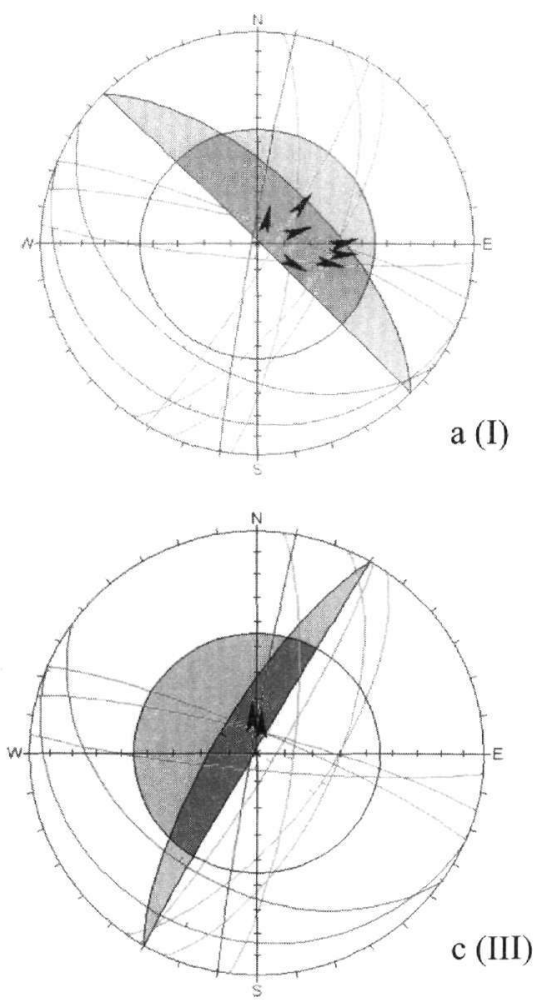

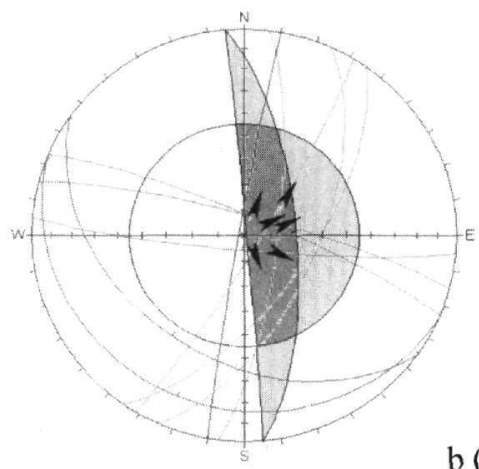

$\mathrm{b}$ (II)

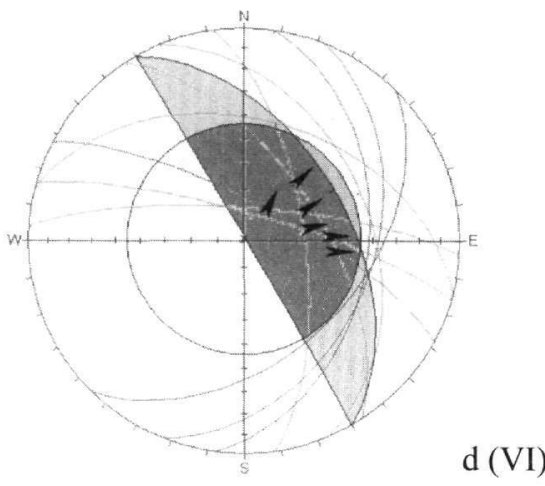

Figure 2 - Wedge sliding (dark arrows) defined by major discontinuities' planes at slopes I -IV (fig. 1) in relation with slope plain geometries and friction angle

The statistical evaluation of a great number of discontinuities measured within the limestone formation of Koritsa peninsula form two (2) main systems and eight (8) secondary sets. Measurements include mainly joints as well as a small number of fault surfaces and rare bending. The discontinuities have generally smooth planar surfaces with various spacing, ranging from very closed to open, locally infilling with reddish clayey material.

As presented in Figure 2a, b, c, instability problems may occur all along the northern natural and lakeside road cut slope. The height of the natural slopes generally exceeds $30 \mathrm{~m}$, while the inclination of the slope varies between $55^{\circ}-90^{\circ}$. Instabilities may include slide of wedges formed by the joints' sets, as well as planar rock failures. Although in most cases the size of the detached rock fragments is small, sliding blocks of several cubic metres of volume may also occur. 
A number of ten (10) discontinuities sets were also distinguished within the unit of dolomitic limestones. Figure $2 \mathrm{~d}$ shows their general distribution, as well as the dominant directions of wedge and planar form of rock failure.

Taking into account that the extreme seasonal changes of climatic conditions farther facilitate rock falls, the risk of injuring people, using the roads constructed at the base of the above slopes is quite high. A further detailed study is needed in order to take the appropriate prevention and protectionmeasures.

\subsubsection{Subsidence phenomena}

As mentioned above, subsidence phenomena occur within the embankment zone, developed all along the lakeside of the southern entrance of the old town, in a zone of about $50 \mathrm{~m}$ wide by $2000 \mathrm{~m}$ long. The overloading of the underlying soft marshy deposits led them gradually to side slip towards the lake, where small "islands" were floated to the surface in a distance of 20-30 m from the shore. Although light constructions were founded on the backfilling zone, ground subsidence phenomena have been occurred. Subsidence trend is still in progress, resulting in local flooding of the lake, while damages on the existing structures occur within a distance of about $80 \mathrm{~m}$ from the shore (Fig. 3).
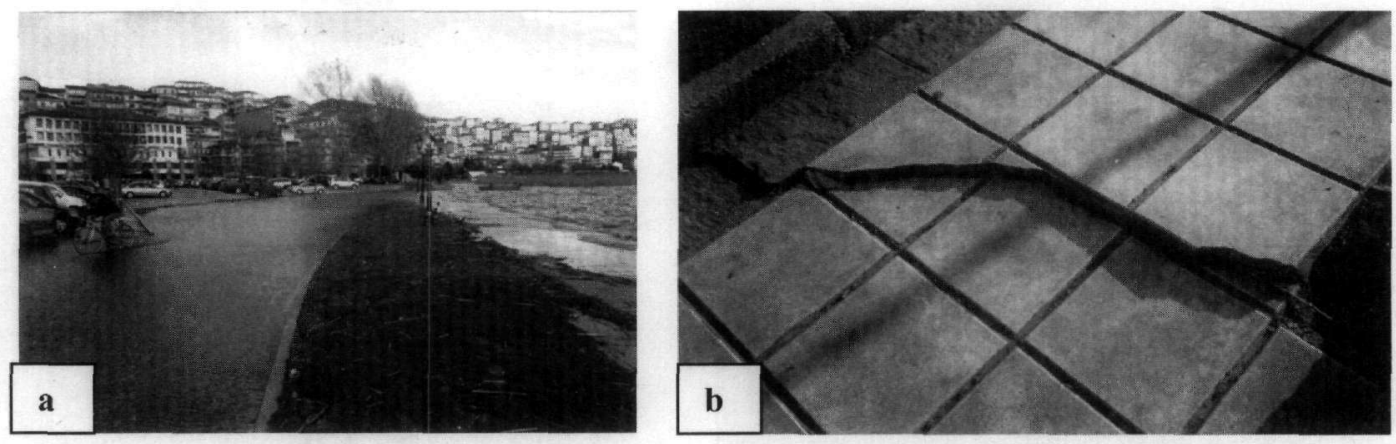

Figure 3 - a) Flooding of the lake due to ground subsidence. b). Damages in structures close to the lakeside

\section{Conclusion}

Engineering geological mapping of urban areas becomes more and more important and efficient nowadays, as a tool for the analysis and evaluation of physico-mechanical data for urban environmental planning. Hence, it is necessary to optimise the process of engineering geological mapping, because, this way, the final result can be achieved faster and with a better quality. It is necessary to consider potential disturbance versus preservation of the required balance, both of natural and of engineering systems affected by factors of the geological environment.

The large-scale engineering geological map traces the basic geological and geotechnical conditions of the foundation ground of Kastoria town. Eleven (11) engineering geological units were distinguished as lithological foundation ground detailed description of their physical condition, thickness and geotechnical characteristics. Instable areas with high rockfall susceptibility and subsidence phenomena were also identified, where farther detail engineering geological study is needed, in order to quantify the critical parameters and determined the appropriate protection measures.

\section{Acknowledgments}

This paper presents results of the research program of IGME, "Geotechnical Data of West Macedonia" undertaken from the West Macedonian Region, in the frame of the Third Community Support Framework cofinanced by the EEC (75\%) -Third European Community Support Framework- and the Hellenic State (25\%).. 


\section{References}

ASTM (American Society for Testing and Materials), 1994. Annual Book of ASTM Standards, Construction: Soil and Rock. ASTM, Publications, vol.04.08, NY, 1225pp.

Barton, N., Lien, R., and Lunde, J., 1974. Analysis of rock mass quality and support practice, In tunnelling and guide for estimating support requirements, Norwegian Geotechinical Institute. Internal Report No. 106.

Bieniawski, Z. T., 1989. Engineering rock mass classification, John Wiley and Sons, New York, U.S.A.

IAEG-UNESCO, 1976. Engineering geological maps, A guide to their preparation UNESCO Press, Paris.

IAEG Mapping Commission, 1980. Recommended symbols for engineering geological mapping. Bulletin of IAEG, No 24. 